\title{
PART OF MATERNAL OPPRESSION: A STUDY ON ROMANTICISM AND STIGMA OF THE ROLE OF HOUSEWIVES AND WORKING MOTHERS
}

\author{
Khoniq Nur Afiah \\ Universitas Islam Sunan Kalijaga Yogyakarta, khoniqnurafiab@gmail.com \\ Ro'fah \\ Universitas Islam Sunan Kalijaga Yogyakarta, rofah@uin-suka.ac.id
}

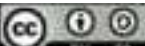

(C)2020 by the authors. Submitted for possible open access publication under the terms and conditions of the Creative Commons Attribution-ShareAlike 4.0 International License (CC-BY-SA) license (https://creativecommons.org/licenses/by-sa/4.0/)

d DOI :bttp://dx.doi.org/10.30983/ bumanisme.v5i2

\begin{abstract}
This study aims to determine the romanticism of the mother's role and the stigma housewives, and working mothers receive. Romance towards the role of the mother often has an unfavorable impact on the mother's condition. Besides romance, stigma is also born and accepted by housewives and working mothers. The stigma continues and impacts the condition and vulnerability of a mother. This research is descriptive qualitative research and analyzed by feminist theory about mothers. The study results stated that the romanticism of the mother's role affected the workload received. This study opens a view about the need for efforts to solve the problem of romanticism in the role of mothers. It is necessary because it is helpful to prevent the occurrence of adverse effects on the condition of the mother's vulnerability. This study also found four stigmas received by working mothers and housewive such as Bachelors who only become full-time mothers, housewives: working spends husband's money, working mothers: never have time to educate children, working mothers: children are entrusted to grandmother, be a grandma's child, housewive are clumsy. Housewive enjoy life because they relax, career women like hanging out, and working mothers have minimal knowledge of kitchen and parenting matters. The two points above are important points that became the findings in this study. bousewife: work spends husband's money, working mother: never has time to educate cbildren, working mother: grandmother leaves children, be grandma's child, housewive are clumsy. Housewive enjoy life because they relax, career women like hanging out, and working mothers have minimal knowledge of kitchen and parenting matters. The two points above are important points that became the findings of this study.
\end{abstract}

Keyword: Feminism, Motherhood, Romanticism, Stigma.

\begin{abstract}
Abstrak
Artikel ini memiliki tujuan mengkaji mengenai romantic meperan ibu dan stigma yang diterima oleh ibu rumah tangga dan ibu bekerja. Romantisme terhadap peran ibu sering memberikan dampak yang kurang baik terhadap kondisi ibu, dan itu bagian dari penindasan. Selain romantisme, Stigma juga lahir dan diterima oleh ibu rumah tangga dan ibu yang bekerja. Stigma tersebut terus diproduksi dan memberikan dampak terhadap kondisi dan kerentanan seorang ibu. Artikel ini adalah penelitian deskriptif kualitatif, dengan teknik pengumpulan data wawancara dan studi dokumentasi, serta dianalisis dengan teori feminis tentang ibu. Hasil penelitian menyatakan bahwa romanticsme peran ibu memberikan efekter hadap beban kerja yang diterima. Artikel ini membuka pandangan mengenai perlunya upaya upaya yang bias menyelesaikan persoalan mengenai romantisme terhadap peran ibu. Hal tersebut diperlukan, sebab berguna untuk menghambat terjadinya dampak buruk terhadap kondisi kerentanan ibu. Artikel ini juga menemukan empat stigma yang diterima ibu bekerja dan ibu rumah tangga seperti: Sarjana kok yang hanya menjadi fulltime mom, ibu rumah tangga: bekerja menghabiskan uang suami, ibu bekerja: tidak pernah memiliki waktu untuk mendidik anak, ibu bekerja: anak dititipkan nenek, jadilah anak nenek, ibu rumah tangga itu kucel. Ibu rumah tangga enak hidupnya karena hanya santai-santai, wanita karir emang hobinya
\end{abstract}


nongkrong, dan ibu bekerja memiliki pengetahuan yang minim terhadap urusan dapur dan pengasuhan. Dua poin diatas menjadi poin penting yang menjadi temuan dalam artikel ini.

Kata Kunci: Feminisme, Peran Ibu, Romantisme, Stigma

\section{Introduction}

Meriam Webster said that a housewife is a woman responsible for all her household needs; these needs are after marriage. It can also be interpreted that a housewife is a woman who focuses on doing domestic work such as doing housework and caring for children, and has no other work. ${ }^{1}$

In this era, women can also participate in the public sphere, such as working in various sectors. It is also part of feminism's struggle for equal space in the public sphere regarding work. The phenomenon of women working is considered normal, but the involvement of women in the world of work can also be positive or negative.

Positive and negative assessments also emerged from the community to construct an understanding of mothers. Negative judgment is something hereinafter referred to as stigma. According to Erving Goffman ${ }^{2}$ stigma is any form of physical or social attribute that reduces a person's social identity and disqualifies that person from acceptance of a person. Meanwhile, according to the Big Indonesian Dictionary, stigma is a negative characteristic attached to a person's personality due to the influence of his environment.

Stigma arises as a result of a mismatch of roles that are carried out with views that are widely constructed. Stigma against mothers also appears in mothers who work with the housewive. Both have the possibility of getting stigma from society.

\footnotetext{
${ }^{1}$ Heri Junaidi, "Ibu Rumah Tangga: Streotype Perempuan Pengangguran” 12 (2017): 12.

${ }^{2}$ Erving Goffman, Stigma: Notes on The Management of Spoiled Identity (America: Prentice Hall, 1963).
}

The understanding that society constructs about mothers is very diverse. Mothers also have complex roles, from nurturing to making a living. It is not unusual for a mother to have a career in this era, but it is not uncommon for mothers to only focus on caring for and doing domestic work.

The construction of public understanding about mothers as fully responsible for child care is one of the triggers for the stigma against mothers. The public's understanding that a mother is fully responsible for the care of children and the welfare of children is highly dependent on the pattern of parenting carried out by a mother. Mothers are also seen as the figure of everything in child care.

The construction of the mother as the main person in charge of parenting is also come with a romantic view of the mother. Mothers are often seen as strong figures, have broad affection, and have extraordinary patience. ${ }^{3}$ This perspective also greatly affects the workload received by a mother. The workload is continuously delegated due to romantic views and the awareness that a mother also has the right to rest and have space for herself.

This stigma that is born is also the influence of the construction of a mother's romanticism. These romantics towards a mother will continue to grow and trigger the birth of stigma against mothers. This romanticism should be slowly attacked in

${ }^{3}$ Putri Limilia dan Ditha Prasanti, "Representasi Ibu Bekerja vs Ibu Rumah Tangga di Media Online: Analisis Wacana pada Situs Kompasiana.Com," Kafa 'ab: Journal of Gender Studies 6, no. 2 (31 Desember 2016): 133, https://doi.org/10.15548/jk.v6i2.140. 
various ways, one of which is by understanding that parenting is the responsibility of a wife and a husband.

Researchers are interested in seeing how romance exists in working mothers and housewive and how these problems receive stigma. However, before going any further, the researcher also conducted a literature review on previous research. Several similar studies, particularly regarding housewive and stigma against women, have also been conducted.

Nuzula researched stigma ${ }^{4}$ against mothers, focusing on designing a product in the form of content about single mothers to reduce the existing stigma. This product or content is then campaigned and directed to someone to cultivate a positive view of single mothers due to divorce. The products used for the campaign are science videos, social media, websites, print ads, transportation ads, and ambient media, which are placed at several points in Jakarta. Research on stigma against veiled women has also been carried out by Rahman and Syafiq $^{5}$ who said that the main motivation for veiled women was religious observance and keeping away from sexual objects. Thus, veiled women feel ready to face the stigma of fanaticism, being considered terrorists, and being avoided by those around them. However, this veiled woman already has a strategy in dealing with the existing stigma, such as ignoring and acknowledging society's negative views towards her. Junaidi ${ }^{6}$ has also conducted research related to the stereotype of housewive.

\footnotetext{
${ }^{4}$ Kartika Firda Nuzula, "Perancangan Kampanye Mengurangi Stigma terhadap Ibu Tunggal" (Skripsi, Solo, Universitas Sebelas November, 2021).

${ }^{5}$ Alif Fathur Rahman, "Motivasi, Stigma dan Coping Stigma pada Perempuan Bercadar," 2017, 13. 'Junaidi, "Ibu Rumah Tangga: Streotype Perempuan Pengangguran.”
}

The study said that being a housewife is not a lowly job, so that it is necessary to raise awareness to the broader community that housewives bear a burden. In addition, this article also discusses the misconceptions about housewive who are considered lighter when doing housework than mothers who work outside the home. Research on the role of mothers as drivers of state programs has also been discussed by Wicaksono ${ }^{7}$. The results of his research explain that the ideology about mothers is very massively voiced to this day. This gave birth to the role of mothers as posyandu cadres to volunteer in the success of programs organized by the government or the state, but the volunteerism was also grounded in the existence of a decree and the incentives provided so that they work for some form of accountability. This in turn signals a reciprocal response between Posyandu cadres and the state. Fitri has also conducted research on stigma against women ${ }^{8}$ This article focuses on looking at the stigma against female ex-prisoners who commit crimes. Stigma that appears include criminals, people who cannot be trusted, and being labeled as prisoners makes it difficult for them to adjust, find it difficult to find work, and become antisocial.

The description of the explanation of previous research does indeed provide answers to the many studies carried out on the stigma of women, especially the stigma of working mothers and housewives. However, this article will try to look further into romanticism as something that is considered common but, indirectly, is part

${ }^{7} \mathrm{M}$ Arief Wicaksono, "Ibuisme Masa Kini: Suatu Etnografi tentang Posyandu dan Ibu Rumah Tangga," Indonesian Journal of Anthropology 1 (2016): 13.

${ }^{8}$ Wanda Fitri, "Perempuan dan Perilaku Kriminalitas: Studi Kritis Peran Stigma Sosial Pada Kasus Residivis Perempuan," Kafa ab: Journal of Gender Studies 7, no. 1 (22 Juni 2017): 67, https://doi.org/10.15548/jk.v7i1.155. 
of the oppression of women or mothers. This article not only discusses the romance of the mother's role as a form of oppression, but this article will also explore stigma as another form of oppression that mothers also accept. Furthermore, the two forms of oppression then hit a mother simultaneously.

In addition, this article reveals that this form of oppression does not only stop at one criterion of motherhood. Field data show that working mothers and housewives both receive oppression, even the aforementioned forms of oppression.

\section{Methods}

This article will be using qualitativeresearch ${ }^{9}$ that focuses on looking at social situations related to the role of a mother. This article has a research objective: to reveal how romanticism occurs in working mothers and housewives and how they receive the stigma. The research will analyze several reality phenomena and shows about working mothers and housewive.

This article has two data sources. The primary data sources were interviews with working mothers and housewives, four people. They are mothers with the status of housewives or working mothers, as well as members of the Women's Study Council group in Wonokerto Leksono Village, Wonosobo, Central Java and the secondary data was obtained by using a documentation study technique from the YouTube Chanel Sorabel program entitled Stigma of Housewives and Working Mothers which was uploaded on December 22, 2019. Other secondary data is taken from several YouTube shows, journal articles, or other writings related to this article.

${ }^{9}$ Muhammad Idrus, Metode Penelitian Ilmu-ilmu Sosial: Pendekatan Kualitatif dan Kuantitaif (Yogyakarta: UII Press, 2007).

\section{Discussion}

\section{Feminist Theory About Mother}

The feminist theory of mother argues the existence of a portrait of a mother who has an intuitive caregiver, naturally equipped and available to care for her children. Mothers are also expected to have anticipation and respond to all forms of needs and desires of their children. In this regard, feminists oppose such a portrait because a mother gives everything selflessly and fulfills all forms of ideals of an individual child triggers a negative consequence.

Devies in her research article, also explains that social theorists also oppose the paradigm which says that the mother's responsibility for children is an ideal parenting rule and that best suits children's psychosocial needs. ${ }^{10}$ This means that the mother will become a complete individual who is perfectly responsible for the upbringing of a child. Parenting a mother is the absolute most ideal for the needs of a child.

It happens because mothers are seen as an expression of care and love. These two expressions are based on the nature of women as human beings who can give birth and breastfeed. The nature of women then influences society in constructing a knowledge that says that the mother is the only owner of the ideal parenting style.

The paradigm of parenting as the full responsibility of a mother also triggered the appearance of motherhood. The concept says that a mother is responsible for raising children and the mother's work in raising children is carried out continuously. A mother's work as a child caretaker, which is

${ }^{10}$ Linda Davies, Sara Collings, dan Julia Krane, "Making Mother Visible: Implicaton for Social Work Practice and Education in Child Welfare," Journal ofthe Association for Research on Mothering, 2, 5 (2003): 15967. 
carried out continuously, is born because of the assumption that the mother is the ideal figure in child care. In addition to parenting, mothers also have homework and also as a career woman

Feminists oppose romantic concepts such as the ideal of motherhood. This opposition is manifested by giving a little room to a mother that they are also natural to experience ambivalence. Cultural construction says that mothers are the best caregivers who never get angry, do not get bored and even always like children. This view of the construction is something called the romanticism of the mother's role.

\section{Mother Role Romanticism Concept}

Romanticism can be interpreted with something that is like in a romance story, is intimate, exciting. The romanticism of the mother's role can be interpreted as an act that considers that a mother's behavior is something intimate, romantic, exciting. Talking about the role of mothers, we need to look at some expert opinions regarding the role of mothers.

The romance of a mother's role assumes that the mother is an intuitive influence, naturally equipped and available to care for her children. In this romantic portrait of mothers, they have demands to anticipate and respond to all the needs and desires of their children.

The portrait of this romanticism then has negative consequences for a mother. Because, mothers will try to fulfill their children's dreams and do it selflessly. This condition then harms the condition of a mother's vulnerability, such as blaming herself when a child being cared for by a mother experiences problems.

That is, that is actually mother's romance $^{11}$ is the assumption that comes

\footnotetext{
${ }^{11}$ Davies, Sara Collings, dan Julia Krane.
}

from the surrounding environment of a mother. This assumption states that the mother is the ideal caregiver figure, the mother is the person who has full responsibility for the upbringing of her children, the mother is the person who best fits the child's psychosocial needs.

These assumptions are continuously produced and will encourage mothers to internalize them to give birth to a sense of wanting to create all the assumptions given to them even though this assumption is a heavy burden that is impossible to be fully realized. Thus, this in turn harms the condition of a mother.

This romance towards the mother's role does indirectly look comfortable and without a burden on the mother figure. Because it is produced continuously and internalized. Without realizing it, a mother assumes that this is a common occurrence, even though it has serious effects implicitly $^{12}$.

Feminists say that it is necessary to give space and acknowledge ambivalence to mothers ${ }^{13}$. This ambivalence confession is like an acknowledgment that a mother is also a person who can feel the conditions of hate and love at one time for her child. This ambivalence arises because of the influence of fatigue because a mother receives too much burden.

Helen Jaqueline McLaren explains that women have multiple roles, in the article calling them the triple burden ${ }^{14}$. The article explains three burdens of roles that must be completed: production, reproduction, and community sectors. Production is related to the work or career of a woman who has the

\footnotetext{
${ }^{12}$ Davies, Sara Collings, dan Julia Krane. ${ }^{13}$ Davies, Sara Collings, dan Julia Krane.

${ }^{14}$ Helen Jaqueline McLaren dkk., "Covid-19 and Women Triple Burden: Vignetters From Srilangka, Malaysia, Vietnam and Australia," Journal Social Science 9 (27 April 2020).
} 
responsibility to complete the responsibilities of her workplace. This reproduction is related to her role as a mother who has to breastfeed, conceive and experience menstruation, while the burden of the community is related to domestic work such as taking care of children, taking care of her husband, and housework which is considered only to be done by a woman or mother.

The explanation above provides an introduction that roles run the effect of vulnerability on a woman or mother. The romantic behavior of a mother's role is also part of what triggers the abovementioned role and is produced continuity until it gives birth to oppression.

Romance is one of the triggers for the birth of a mother's vulnerability and even part of the oppression. The romance of the mother's role, which considers the mother to be a strong figure, always has love, without self-respect, will slowly have a negative impact. ${ }^{15}$ The negative impact is that these multiple roles continue to be given and give a double burden and result in a vulnerable condition for a mother.

This romance is fundamental in the life of the mother. In fact, due to the strong culture of romanticism on the role of mothers, mothers also end up labeling themselves with romantic jargon themselves. As stated by Melati:

"The definition of a mother is someone who gives birth to a child; her place is irreplaceable; it is a role played by women. Where she gives infinite love, infinite love, sincerity for her children and family"16

The existence of such an assumption requires a more extensive study. The notion

\footnotetext{
${ }^{15}$ Limilia dan Prasanti, "Representasi Ibu Bekerja vs Ibu Rumah Tangga di Media Online."

${ }^{16}$ Melati (Nama Samaran), Wawancara tentang Peran sebagai Ibu, 28 Juni 2021.
}

of her as an irreplaceable figure, she is a person who has infinite love, this can trigger the birth of the dominance of the parenting work that he must complete. In reality, Melati is a working mother who must also complete her workplace responsibilities. This romance needs to be studied more deeply and more broadly regarding the impact that can be born and what efforts can be made so that the condition of mothers as a vulnerable group can be resolved immediately.

\section{Stigma on Housewives and Working Mothers}

Stigma is a negative characteristic that attaches to a person's personality because of the influence of her environment. This stigma is an attempt to label something as a group of people who do not deserve respect. This stigma appears and triggers a group of people who get it to experience discrimination because of the negative labels produced. ${ }^{17}$

Stigma as a negative label is produced by people around or community groups who live side by side with the speakers. Stigma against a mother also appears in housewives and working mothers. So, it would be nice, before discussing stigma, this author discusses housewives and working mothers first. A housewife is a married woman who does not work, spends most of her time taking care of the household, and will inevitably meet with routine tasks every day. Simply put, a housewife is a married woman who has a role as a wife, mother, and homemaker. A working mother is a married woman and has an independent job. It means that working mothers take care of household matters and have a busy life as a form of self-actualization. In reality, housewives and working mothers both get

${ }^{17}$ Dadang Hawari, Manajemen Stress Cemas dan Depresi (Jakarta: Balai Penerbitan FKUI, 2001). 
stigma from the community. The following are the forms of stigma received by working mothers and housewives:

\section{a. Bachelors who only become full- time moms}

The negative assumptions received by housewives include, as received by Mawar, as follows:

"Something that once made me really down, one of which was when other people said: hey, you are an undergraduate, your diploma is useless, you go to college for four years, your parents pay for you very hard, while you, just stay at home. That really hit me hard. Being a fulltime mom is considered as something that is not useful, because all day at home and doing nothing. In fact, being a full-time mom is not that easy, because we work 24 hours starting to take care of our children and husband." 18

The first stigma is the assumption that someone who already has a higher education must become a worker or have a career. Because, the assumption is that a diploma is useless when you are a housewife. In fact, to be a good housewife also requires extensive knowledge. because, in the process of educating children, managing daily needs, regulating emotions also really requires extensive skills and knowledge. However, not many people realize that they immediately give a stigma about education to housewives.

\section{b. Housewife: work spends husband's money}

Housewives are seen as monotonous and unproductive, so there is such a stigma:

${ }^{18}$ Mawar (Nama Samaran), Wawancara tentang Peran Sebagai Ibu, 27 Juni 2021.
"So, people often talk about housewives, for example: housewives spend their husband's money, the ultimate laziness, only have one child yet is still very lazy. It's like we're still talking about laundry, then we don't have any responsibility if we don't make money."

Not having financial independence is also a way to stigmatize a housewife. A housewife is considered as someone who only spends her husband's wealth. But in family life, a husband must meet the family's needs, both his wife and children.

Several previous studies also said that the work of housewives would not be of material value. It means that there is poverty for women, as mentioned by Mansour Faqih about marginalization or a process of economic poverty for women. ${ }^{19}$.

\section{c. Working mother: never has time to educate children}

The view that educating is the main thing a mother or mothers has full responsibility in parenting work. The next view can give a stigma to working mothers who do not have much time to spend with their children in terms of time.

In fact, like previous research that has been done, it is stated that a mother who works during a pandemic like this also still has the burden of raising children, carrying out her production role as a career woman, and serving her husband. These three roles go hand in hand and are seen as ideal roles. ${ }^{20}$

${ }^{19}$ Darmin Tuwu, "Peran Pekerja Perempuan dalam Memenuhi Ekonomi Keluarga: dari Peran Domestik Menuju Sektor Publik," Al-Izzah: Jurnal Hasil-Hasil Penelitian 13, no. 1 (30 Mei 2018): 63, https://doi.org/10.31332/ai.v13i1.872.

${ }^{20}$ Yelly Elanda, "The Construction of An Ideal Mother Amid the Covid 19 Pandemic: Gender Injustice Experienced by Career Women While Working From Home," Journal of Gender Studies 05, no. 01 (2021): 16. 
The condition of idealizing mothers with all three roles that must be carried out results from social construction. So, if one role is not carried out, it will trigger the birth of a bad opinion of a mother. As well as the assumption that working mothers do not have time to educate children. The following is the expression conveyed by Bunga:

"The notion that working mothers do not have enough time for their children. So that they don't have closeness with their children, they will get less love from their mothers. Then, another assumption is that working mothers are also considered less able to provide education to their children",21

Mothers are considered to be fully responsible for parenting. Family life will be more beneficial if parenting is also a shared task. This means that it is necessary to consider the work of both husband and wife in a family. so, get a balance and a fair division of labor.

In this context, Faqih ${ }^{22}$ In his book, he has explained a lot about the importance of the concept of mutual assistance and cooperation which is applied in the family, especially in the process of raising a child. Husband and wife have the same responsibility in the parenting process and the parenting process that involves the concept of mutual cooperation will have a good impact on the growth and development of children so that they get balanced love and attention from a mother and father.

\section{d. Working mother: grandma's child, be grandma's son}

\footnotetext{
${ }^{21}$ Bunga (Nama Samaran), Wawancara tentang Peran sebagai Ibu, Chat WhatsApp, 28 Juni 2021.

${ }^{22}$ Faqihuddin Abdul Qodir, Qiraah Mubadalah (Yogyakarta: IRCiSoD, 2019).
}

The issue of time is again used as a target to produce stigma against working mothers. This is as expressed by sister Melati:

"When children are small and often have to leave work, there must be some talk: it's good, you already have children, you can still work at home. Then there are also rumors that the child has grown up with grandma, later when he grows up he becomes a grandma's child, because he doesn't know his mother." ${ }^{23}$

The stigma that a working mother does not have much time for her child, so she cannot provide the best education for her child continuously. In fact, Melati also explained that she always provides the best service for her child and manages the time as best as possible to complete the role she is carrying out. Of course, getting such a stigma influences a mother's susceptibility to primary psychological conditions.

In fact, according to research conducted by Darwin Tuwu ${ }^{24}$ regarding women workers' role in fulfilling the economy, it is explained that women workers have a profound role in improving the family economy. This increase is evidenced by several fulfillments that occur from the wages of a woman worker. Women who work make their wages to meet the necessities of life such as: increasing their husband's income, children's school fees, daily shopping needs, and there are also several options for saving as an alternative budget if they have urgent and unexpected needs.

The stigma that working women do not have much time with their children and results in inadequate care because they are

\footnotetext{
${ }^{23}$ Melati (Initial name), An interview about the role of housewife.

${ }^{24}$ Tuwu, "Peran Pekerja Perempuan dalam Mememnuhi Ekonomi Keluarga."
} 
cared for by their grandmothers and even claimed to be grandmothers' children can be refuted. In this case, however, the steps chosen by women as described above provide an explanation of the responsibilities of a woman as a mother. The results of work wages are also an effort to meet the needs of the family, including children. So, it is only natural that the stigma about a child raised by a grandmother will become a grandmother's child is something that is painful for a mother, and also has a serious impact on a mother's condition.

\section{e. Housewives are clumsy, different from working mothers}

The increasing development of technology has also entered into various sectors, such as the beauty product industry. Women are colored with the trend of skincare or skincare. The purpose of skincare is none other than beautifying and maintaining healthy skin.

However, this trend did not fully influence the food of the people in general. As someone busy working at home, Housewives is seen as not good at skincare, so the stigma appears wrinkled. This stigma is produced and compared with career women or working mothers who are active outside the home so they have demands to make up. The "kucel" stigma is produced and given to housewives as follows:

"I'm often told that my face is really wrinkled, I've never done skincare, huh?" 25

Even though Kenanga said that he did skincare, because his skin sensitivity is quite high, it has an unfavorable effect on his skin. Kenanga explained that often they are not suitable for using products, so they only use them once or twice, then stop for fear of aggravating the skin.

\footnotetext{
${ }^{25}$ Kenanga (Nama Samaran), Wawancara tentang Peran Sebagai Ibu, 11 Juli 2021.
}

\section{f. Housewives have a good life, just relax}

At first glance, housewives look simple and only do housework. Homework is often seen as simple, but being a housewife is a 24-hour worker in reality. Jasmine said so:

"As a housewife, I feel very busy. Because I also have to take care of my parents at home.In addition to serving her husband and educating children. The children who are still small also make me have to have extra assistance.Children also learn at home not in tutoring institutions. Still cooking, and cleaning the house. Yes, the job is actually 24 hours a day." 26

The explanation given by Melati refutes views and stigma about housewives having plenty of time to relax. The role of women as domestic workers is very clear in the explanation given by Melati.

Klesssemen has researched the image and reality of women. The study explains that being a housewife is a very timeconsuming job. Women who choose to be housewives sometimes do work before sunrise. When children and husbands are active outside the home, housewives are also sometimes still faced with other domestic work and when husbands and children are at home, she has to serve and accompany them while they are doing activities at home. Thus, the stigma about housewives who work casually should be countered with the reality that exists in the daily life of housewives as described above. ${ }^{27}$

\section{g. Career women really like hanging out after work}

${ }^{26}$ Melati (Nama Samaran), Wawancara tentang Peran sebagai Ibu.

${ }^{27}$ Klasselmen dan Amy, Women Image and Realities, A Multicultural Anthology, Second Edition. (California: Mayfield Publishing Company, 1999). 
Religious experts have widely discussed the role of women in the public sector. In Islam, the issue of the role of women in the public sector was discussed at the NU National Conference in West Nusa Tenggara in 1997 and the 30th congress in Lirboyo in 1999. The ulama meeting in the big event gave birth to a fatwa that allowed women to take part in the public sphere.

The fatwa is based on that a good human being is beneficial to oneself and others. All women should understand this as a basis for applying it in everyday life.

Working mothers tend to have broad relationships because of their space in the public sphere. Hanging out with coworkers is one thing that is seen as unfavorable and triggers the birth of a stigma for working mothers, as explained by Orchid:

"I am often viewed negatively if for example I meet neighbors and then hang out with my co-workers. In fact, it's not just hanging out for a long time, just having lunch after coming home from work.Besides, I don't often eat out with coworkers. Only once in a while, as entertainment so you don't get tired and bored.But people have already looked at it and thought it was nothing. Even though if I want to hang out or eat out, my husband must also have permission and that's fine as long as I know the time. I also hang out often while waiting for the children to come home from school”28

The description given by Anggrek explains that there is a sense of responsibility he has for his child. Meeting with friends or hanging out is not necessarily without rules, as a wife she also does not step over her

\footnotetext{
${ }^{28}$ Anggrek (Nama Samaran), Wawancara tentang Peran Sebagai Ibu, Chat WhatsApp, 11 Juli 2021.
}

husband's permission. The reason for waiting for children is also part that shows the side of responsibility as a mother to look after and care for her child.

This means that getting together with friends after coming home from work and having good reasons should be understood more deeply. There should be no need to be careless in discussing it for longer or even creating stigma. Because this triggers a lot of bad effects on women.

However, the stigma was born based on existing social constructions. so, if there is a phenomenon that is not following the construction then it will be considered deviant.

\section{h. Working mothers have little knowledge about the kitchen and taking care of children}

The focus on doing work from the office and having more of the outside world also triggers the birth of a stigma that mothers are not experts in kitchen matters and taking care of children. It really disturbs the condition of a working mother, this has been conveyed by Matahari:

"I am also often hit at the recitation by Mrs. A. She seems to see that I am incompetent in terms of the kitchen and child-rearing, because I am busy going to the office from morning to evening. That's why I prefer not to attend training gatherings, because I like to be offended myself, so I think about it everywhere." 29

The stigmas produced harm the mother's psychological condition. These views continue to be produced which increasingly corners a mother. whereas, before getting stigmatized, the condition of women has become a role group because of

\footnotetext{
${ }^{29}$ Matahari (Nama Samaran), Wawancara tentang Peran Sebagai Ibu, Chat WhatsApp, 11 Juni 2021.
} 
the cultural construction that has developed to this day.

\section{Conclusion}

This article provides an overview of the romanticism of the developing role of mothers in society. The role of mother is considered as intimate, romantic and exciting. Simply put, the mother is described as a romantic figure such as full of affection, has infinite love, does not have a sense of fatigue, the figure of the owner of the ideal parenting pattern and other romantic images. This romance can harm the condition of a mother, such as increasing the level of vulnerability. Romanticism is very likely to give birth to a double burden on the mother, which is the root or part of the mother's oppression.

This article also reveals some of the stigmas received by working mothers and housewives. Both working mothers and housewives get a bad stigma from society.

Stigma as a form of oppression born from society is found in this article. The stigma is produced by groups of people who live side by side with them. This article finds four stigmas: A graduate who only becomes a full-time mom, Housewife: works to spend husband's money, Working mother: never has time to educate children, Working mother: grandmother leaves children, becomes grandmother's child. It means that stigma against mothers can be produced from any side, which is a sign that the condition of a mother also needs more attention.

The romanticism of the mother's role and stigma are two forms of oppression against mothers in society. Both have a bad impact on the condition of a mother. It means that there is a need to build public awareness about the need to provide space for women.

\section{References \\ Journal}

Davies, Linda, Sara Collings, dan Julia Krane. "Making Mother Visible: Implicaton for Social Work Practice and Education in Child Welfare." Journal ofthe Association for Research on Mothering, 2, 5 (2003): 159-67.

Elanda, Yelly. "The Construction of An Ideal Mother Amid the Covid 19 Pandemic: Gender Injustice Experienced by Career Women While Working From Home."Journal of Gender Studies 05, no. 01 (2021): 16.

Fitri, Wanda. "Perempuan dan Perilaku Kriminalitas: Studi Kritis Peran Stigma Sosial Pada Kasus Residivis Perempuan." Kafa'ab: Journal of Gender Studies 7, no. 1 (22 Juni 2017): https://doi.org/10.15548/jk.v7i1.1 55.

Limilia, Putri, dan Ditha Prasanti. "Representasi Ibu Bekerja vs Ibu Rumah Tangga di Media Online: Analisis Wacana pada Situs Kompasiana.Com." Kafa ab: Journal of Gender Studies 6, no. 2 (31 Desember 2016): 133. https://doi.org/10.15548/jk.v6i2.1 40.

McLaren, Helen Jaqueline, Karen Rosalind Wong, Kieu Nga Nguyen, dan Komalee Nadeeka Damayanthi Mahamadachchi. "Covid-19 and Women Triple Burden: Vignetters From Srilangka, Malaysia, Vietnam and Australia." Journal Social Science 9 (27 April 2020).

Tuwu, Darmin. "Peran Pekerja Perempuan dalam Mememnuhi Ekonomi Keluarga: dari Peran Domestik 
Menuju Sektor Publik." Al-Iz:ah: Jurnal Hasil-Hasil Penelitian 13, no. 1 (30 Mei 2018): 63. https://doi.org/10.31332/ai.v13i1. 872.

Wicaksono, M Arief. "Ibuisme Masa Kini: Suatu Etnografi tentang Posyandu dan Ibu Rumah Tangga." Indonesian Journal of Anthropology 1 (2016): 13.

\section{Books}

Dadang Hawari. Manajemen Stress Cemas dan Depresi. Jakarta: Balai Penerbitan FKUI, 2001.

Erving Goffman. Stigma: Notes on The Management of Spoiled Identity. America: Prentice Hall, 1963.

Junaidi, Heri. "Ibu Rumah Tangga: Streotype Perempuan Pengangguran" 12 (2017): 12.

Kenanga (Nama Samaran). Wawancara tentang Peran Sebagai Ibu, 11 Juli 2021.

Klasselmen dan Amy. Women Image and Realities, A Multicultural Anthology, Second Edition. California: Mayfield Publishing Company, 1999.

Muhammad Idrus. Metode Penelitian Ilmu-ilmu Sosial: Pendekatan Kualitatif dan Kuantitaif. Yogyakarta: UII Press, 2007.

Nuzula, Kartika Firda. "Perancangan Kampanye Mengurangi Stigma terhadap Ibu Tunggal." Skripsi, Universitas Sebelas November, 2021.

Qodir, Faqihuddin Abdul. Qiraah Mubadalah. Yogyakarta: IRCiSoD, 2019.

Rahman, Alif Fathur. "Motivasi, Stigma dan Coping Stigma pada Perempuan Bercadar," 2017, 13.

\section{Other's}

Anggrek (Nama Samaran). Wawancara tentang Peran Sebagai Ibu. Chat WhatsApp, 11 Juli 2021.

Bunga (Nama Samaran). Wawancara tentang Peran sebagai Ibu. Chat WhatsApp, 28 Juni 2021.

Matahari (Nama Samaran). Wawancara tentang Peran Sebagai Ibu. Chat WhatsApp, 11 Juni 2021.

Mawar (Nama Samaran). Wawancara tentang Peran Sebagai Ibu, 27 Juni 2021.

Melati (Nama Samaran). Wawancara tentang Peran sebagai Ibu, 28 Juni 2021. 